\title{
ANALISIS FAKTOR PENYEBAB MASYARAKAT DESA GURU KINAYAN TETAP BERTAHAN DI ZONA MERAH GUNUNG SINABUNG
}

\author{
Jian Maxriz \\ Jurusan Pendidikan Geografi, Fakultas IImu Sosial \\ Universitas Negeri Medan \\ JI. WILLEM Iskandar Psr V, Medan, 20221, Indonesia \\ Email: jianmaxriz@gmail.com
}

\begin{abstract}
Abstrak
Desa Guru Kinayan merupakan salah salah satu di antara belasan desa yang berada di dalam radius zona merah gunung sinabung, desa ini juga terkena dampak dari erupsi gunung sinabung cukup parah, gunung Sinabung yang erupsi terhitung sejak Agustus 2010 sampai dengan Februari 2018 mengakibatkan setengah dari desa ini sudah tidak dapat di huni kembali karna rumah-rumah masyarakat telah rusak bahkan sebagian telah hancur di akibatkan terkena dampak dari erupsi gunung Sinabung. Walaupun desa Guru Kinayan telah di tetapkan masuk dalam zona merah gunung Sinabung dan sebagian dari desa ini sudah tidak dapat di huni kembali, namun masih banyak masyarakat yang tetap bersikukuh tinggal di lokasi tersebut.Penelitian ini bertujuan untuk mengetahui apa penyebab masyakarat desa Guru Kinayan tetap bertahan di zona merah Gunung Sinabung, dan bagaimana kebijakan relokasi yang di lakukan pemerinta daerah Karo. Mengingat kompleksnya faktor yang menyebabkan masyarakat tetap bertahan di zona merah tersebut, membuat pendekatan kualitatif di pilih dalam penelitian ini dengan metode wawancara, seluruh masyarakat desa Guru Kinayan merupakan populasi dalam penelitian ini dengan pengambilan sampel berdasarkan masyarakat yang berada di lokasi tersebut. Penelitian ini akan menghasilkan informasi penyebab masyarakat desa Guru Kinayan tetap bertahan di zona merah gunung Sinabung yaitu meliputi: faktor ekonomi dan fakor Pendidikan anak, serta program kebijakan relokasi pemerindah daerah yang kurang efektif.
\end{abstract}

Kata Kunci: Desa Guru Kinayan, Gunung Sinabung, Zona Merah

\begin{abstract}
Guru Kinayan Village is one of a dozen villages within the radius of the red zone of Mount Sinabung, this village is also affected by the eruption of Mount Sinabung quite badly, Mount Sinabung which erupted from August 2010 to February 2018 resulted in half of this village it cannot be resettled because the people's houses have been damaged and some have been destroyed and have been affected by the eruption of Mount Sinabung. Although the Guru Kinayan village has been included in the red zone of Mount Sinabung and a part of this village cannot be resettled, there are still many people who remain adamant about staying in that location. This study aims to find out what causes the community of Guru Kinayan to survive in the red zone of Mount Sinabung, and how is the relocation policy carried out by the Karo regional government. Given the complexity of the factors that led to the community remaining in the red zone, making the qualitative approach chosen in this study using the interview method, all the people of the Guru Kinayan village were the population in this study with sampling based on the community in that location. This research will produce information on the causes of the community of Guru Kinayan village to remain in the red zone of Mount Sinabung, which includes: livelihood factors and factors for children's education, as well as a program of relocation of regional governments that are less effective.
\end{abstract}

Keywords: Guru Kinayan Village, Mount Sinabung, the Red Zone 


\section{PENDAHULUAN}

Desa Guru Kinayan merupakan salah salah satu di antara tujuh belas desa yang berada di dalam radius zona merah gunung sinabung, Desa ini juga termasuk kedalam tujuh desa yang tidak dapat di tempati kembali sehingga dilakukan relokasi, dampak dari erupsi gunung Sinabung berdampak parah terhadap desa tersebut, Pada awalnya, Gunug Sinabung termasuk dalam gunung api tipe $B$ yang tercatat pernah erupsi sebelum tahun 1.600 (Pratomo, 2006). Namun kembali aktif (Fianet, 2014), terhitung sejak Agustus 2010 sampai dengan Februari 2018. Gunung ini mengalami erupsi dan mengakibatkan setengah dari desa Guru Kinayan sudah tidak dapat di huni kembali karna rumahrumah masyarakat telah rusak bahkan sebagian telah hancur di akibatkan terkena dampak dari erupsi tersebut (Ebo, 2010).

Walaupun desa Guru Kinayan telah di tetapkan masuk dalam zona merah gunung Sinabung dan sebagian dari desa ini sudah tidak dapat di huni kembali, namun masih banyak masyarakat yang tetap bersikukuh tinggal di lokasi tersebut (Oktorie, 2018). Pemerintah daerah Karo juga sudah berusaha merelokasi masyarakat di desa ini dengan kebijakan-kebijakan yang telah di keluarkan, namun semua usaha itu tetap siasia karna masyarakat enggan keluar dari zona merah gunung Sinabung.

Mengetahui banyaknya dampak yang diakibatkan oleh letusan Gunung Sinabung baik secara materil maupun non materil, mengharuskan pemerintah setempat mengeluarkan berbagai kebijakan. Namun, kebijakan yang telah dikeluarkan dan dilakukan dirasakan belum optimal, sehingga perlu dilakukan evaluasi kebijakan yang efektif, holistik dan tepat sasaran (Hermon, 2009; Hermon, 2015; Hermon, 2016). Hal ini terbukti dengan adanya masyarakat yang mengeluh atas kebijakankebijakan yang diberikan oleh pemerintah.

Desa Guru Kinayan merupakan desa yang secara administratif masuk kedalam kecamatan Payung, Kabupaten Karo, Sumatera Utara. Desa tersebut termasuk salah satu desa yang masuk dalam zona merah gunung Sinabung dan termasuk dalam desa yang mendapat relokasi dari pemerintah daerah karo, yaitu berupa peberian dana ganti rugi untuk pembangunan rumah di daerah luar zona merah, Dana tersebut di berikan pemerintah daerah kepada ketua Aron, ketua aron merupakan penanggung jawab beberapa kk atau dapat di katakan sebagai ketua kelompok, pencairan dana langsung dari pemerintah daerah ke pada pengembang. dimana pengembanglah yang mengelola uang tersebut dalam pembangunan rumah dan pembayaran lahan.

Kebijakan program relokasi yang di lakukan pemerintah terbagi kedalam dua gelombang, yaitu gelombang pertama relokasi di lakukan terhadap 3 desa dengan pemberian ganti rugi tanah seluas $5000 \mathrm{~m}$ dan rumah yang terletak di daerah desa sihosar dan program relokasi gelombang kedua berupa pemberian dana ganti rugi sebesar Rp. 110.000.000 kepada 4 desa, salah satunya termasuk desa Guru Kinayan.

Adapun kebijakan yang telah di keluarkan yaitu pemberian bantuan dana sebesar $\mathrm{Rp} 110.000 .000$ sebagai uang ganti rugi untuk membangun rumah kembali di tempat lain (diluar zona merah). Namun kebijakan tersebu di nilai tidak efektif karna pada realitanya masih banyak masyarakat yang tetap bertahan di zona merah tersebut tanpa mempedulikan keselamatannya sendiri. Pemerintah juga menerapkan pemberian insentif bagi pengungsi di radius $5 \mathrm{~km}$ dan ganti rugi perumahan masyarakat yang dilanda bencana dengan dana anggaran Rp148,25 miliar (Supriono, 2018)

\section{METODE PENELITIAN}

Penelitian ini di lakukan di desa Guru Kinayan pada 8 - 9 November 2018, dengan alokasi waktu penelitian -+ 4 jam/hari menggunakan pendekatan kualitatif dan metode wawancara serta observasi. Dengan populasi seluruh masyarakat desa Guru Kinayan yang masih tetap bertahan di desa tersebut serta pemilihan sampel di lakukan secara acak terhadap masyarakat yang masih tetap bertahan di desa tersebut dan berdasarkan status. Adapun instrument yang di gunakan dalam penelitian ini berupa draf pertanyaan wawancara dan lembar observasi. Kepala desa Rimo Kayu, Ketua Aron dan masyarakat yang di tuakan menjadi sampel utama dalam penelitian ini, Kepala Desa Rimo Kayu di jadikan sebagai sampel karena Kepala Desa Guru Kinayan belum di Lantik dan kepala desa pelaksana tugas tidak sedang berada di lokasi ketika penelitian ini di lakukan. 


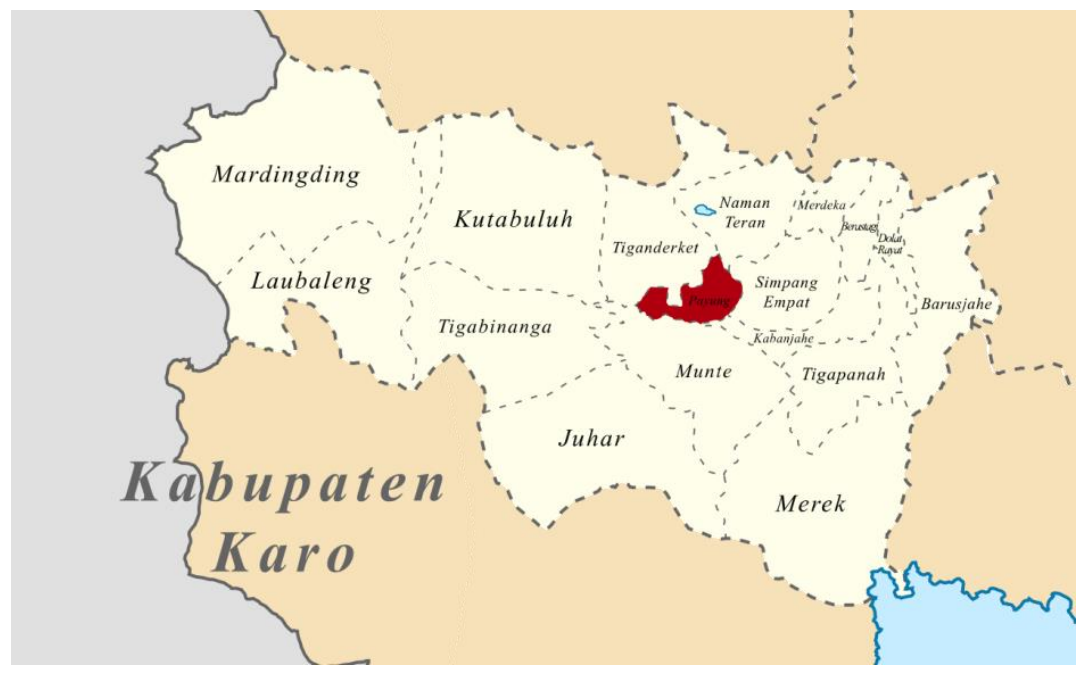

Gambar 1. Peta Kecamatan Payung

Secara administratif Desa Guru Kinayan masuk kedalam kecamatan Payung, Kabupaten Karo, Kecamatan Sumatera Utara. Desa ini berada di ketinggian 1500 mdpl dengan luas wilayah mencapai 11,30 $K M^{2}$, luas tersebut merupakan $23,92 \%$ dari keseluruhan luas total kecamatan payung (BPS Karo, 2017).

Adapun desa-desa yang berbatasan langsung dengan desa Guru Kinayan adalah: Sebelah Utara : Berbatasan dengan desa Suka Meria

Sebelah Timur : Berbatasan dengan desa
Sebelah Selatan : Berbatasan dengan desa Payung

Sebelah Barat : Berbatasan dengan desa Seladi

Terdapat 702 Rumah tangga yang bertempat tinggal di desa ini dengan jumlah penduduk mencapai 2235 jiwa. Mayoritas penduduk di desa ini bekerja sebagai petani karna tanah di desa Guru Kinayan termasuk subur berkat pengaruh dari gunung Sinabung dengan status desa sebagai desa swasembada.

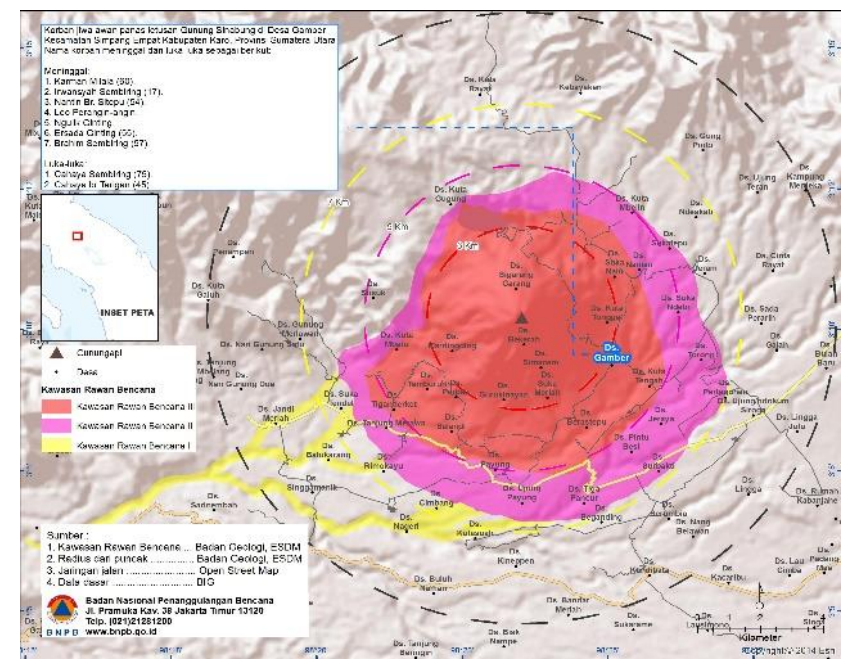

Gambar 2. Peta korban Sinabung

Desa Guru Kinayan merupakan salah satu di antara beberapa desa yang berada di Kawasan zona merah gunung sinabung, dengan radius jarak $3 \mathrm{Km}$ dari kawah gunung Sinabung. Sebagian besar dari desa ini juga sudah rusak parah akibat dampak dari erupsi gunung sinabung.

\section{HASIL DAN PEMBAHASAN Faktor Ekonomi}

Masyarakat di desa Guru Kinayan mayoritas berasa dari suku karo yang di mana $80 \%$ masyarakat di desa ini berprofesi sebagai petani, artinya terdapat 982 jiwa 
yang menggantungkan kelangsungan

hidupnya pada lahan pertanian.

Tabel 1. Banyaknya Tenaga Kerja Berdasarkan Lapangan Pekerjaan

\begin{tabular}{|c|c|c|}
\hline No & Pekerjaan & Jumlah \\
\hline 1 & Pertanian & 982 \\
\hline 2 & Industri Rumah Tangga & 20 \\
\hline 3 & Jasa & 14 \\
\hline 4 & PNS/TNI/POLRI & 38 \\
\hline 5 & Lainnya & 205 \\
\hline & Total & 1259 \\
\hline
\end{tabular}

Lahan pertanian setiap penduduk di desa ini berada di dalam wilayah desa tersebut dan masuk kedalam zona merah gunung Sinabung.

Tabel 2. Luas Wilayah Menurut Jenis Penggunaan Tanah dan Desa ( $\mathrm{Ha})$

\begin{tabular}{llc}
\hline No & Jenis Penggunaan Tanah & Luas (Ha) \\
\hline 1 & Sawah & 55 \\
\hline 2 & Pertanian Non-Sawah & 762 \\
\hline 3 & Lahan Bukan Pertanian & 313 \\
\hline & Total & 1130
\end{tabular}

Sumber: UPT. Dinas Pertanian Kecamatan Payung, 2018

Hal tersebut merupakan factor utama mengapa sebagian masyarakat di desa ini masih memilih untuk tetap bertahan di zona merah gunung Sinabung, walaupun desa ini merupakan salah satu di antara 4 desa yang mendapatkan program relokasi gelombang ke 2 dari pemerintah, yaitu pemberian ganti rugi berupa uang senilai Rp 110.000.000 yang di peruntukkan untuk membangun kembali rumah warga di tempat yang di inginkan oleh warga, tidak di tentukan oleh pemerintah.

Berdasarkan hasil dari wawancara yang kami lakukan terhadap seorang warga di desa Guru Kinayan , menurut pengakuan beliau uang yang di berikan pemerintah tidak sepenuhnya langsung di terima masyarakat, karna uang tersebut di berikan kepada pengembang sehingga beliau merasa tidak mendapatkan 110.000 .000 secara penuh. Uang tersebut di gunakan untuk membangun rumah warga kembali namun walaupun rumah warga sudah selesai di bangun dan sudah bisa di tempati, masyarakat tidak menempati rumah tersebut dan malah tetap bertahan di zona merah dengan alasan ketidak tersediaan air di rumah yang di bangun tersebut. Namun menurut hasil wawancara yang kami lakukan dengan kepala desa Rimo Kayu, keterangan yang di berikan masyarakat di desa Guru Kinayan di bantah oleh beliau, karna menurut beliau rumah yang di bangun dari dana ganti rugi yang di berikan pemerintah sudah lengkap dan layak di huni.

Pasca erupsi gunung Sinabung masyarakat di desa Guru Kinayan merasa bahwa tanah di lahan mereka menjadi lebih subur, dan tanaman yang di tanami oleh masyarakat juga sudah mulai tumbuh subur kembali yang mana sebelumnya kondisi tanaman warga kering dan layu. Tanaman kopi merupakan tanaman yang di pilih kebanyakan masyarakat untuk di usahakan, dan berdasarkan keterangan masyarakat di desa tersebut, harga kopi sedang berada di harga optimalnya sehinggal hal tersebut mendorong masyarakat untuk tetap menjalankan pertaniannya walaupun hal tersebut sangatlah beresiko.

\section{Faktor Pendidikan Anak}

Pendidikan anak merupakan salah satu faktor yang sangat berpengaruh dalam hal ini, di desa Guru Kinayan sendiri terdapat dua Sekolah Dasar (SD) dan satu Sekolah Menengah Pertama (SMP), di kecamatan payung terdapat 10 Sekolah Dasar(SD) dan hanya terdapat 2 Sekolah Menengah Pertama (SMP). tercatat terdapat 286 siswa yang bersekolah di desa guru kinayan, jumlah tersebut merupakan akumulasi siswa SD kelas 1 sampai dengan SMP kelas 3 dengan persentase $220(76,9 \%)$ siswa SD dan $66(23 \%)$ siswa SMP. 
Tabel 3. Jumlah Siswa Sekolah Dasar (SD)

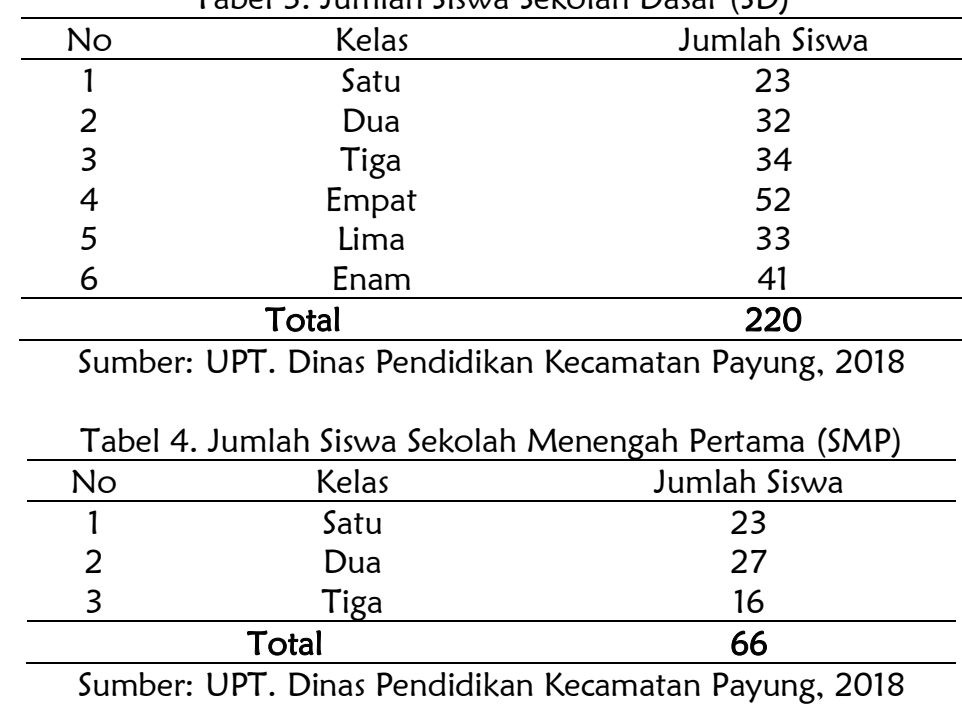

Untuk SMA sendiri belum ada terdapat di desa tersebut bahkan di kecamatan payung sendiri belum terdapat satupun SMA, sehingga anak-anak di desa ini untuk jenjang SMA kebanyakan bersekolah ke kecamatan lain.

Berdasarkan keterangan yang di berikan oleh warga saat di lakukan wawancara di desa Guru Kinayan, tempat relokasi yang di bangun berada jauh dari sekolah tempat anak-anak mereka bersekolah baik itu SD maupun SMP dan SMA, faktor tranfortasi dan rumitnya menurut masyarakat proses untuk mengurus pindah sekolah menjadi alasan utama masyarakat tetap memilih untuk menyekolahkan anaknya tetap di tempat semula, sehinggal hal tersebut berimbas pada pilihan masyarakat untuk tetap bertahan di desa tersebut. Untuk berangkat ke sekolah anak-anak di desa ini tidak membutuhkan biaya/ongkos transportasi karna jarak sekolah yang dekat memungkinkan para siswa untuk berjalan kaki, sebaliknya jika masayrakat pindah ke tempat relokasi makan untuk berangkat ke sekolah membutuhkan biaya transfortasi yang dapat berkisar antara $2000-5000$ rupiah untuk sekali perjalanan, sedangkan untuk biaya pulang pergi di perkirakan dapat mencapai 4000 - 10.000 rupiah, memang biaya tersebut tidaklah terlalu besar, namun jika di akumulasikan dalam jangka waktu satu bulan, biaya tersebut dapat mencapai 120.000 - $300.000 \mathrm{Rp}$ untuk biaya transportasi satu orang anak. Tentu hal tersebut akan memberatkan kepada perekonomian keluarga mengingat pendapatan masyarakat juga tergangung akibat dari erupsi gunung Sinabung.

\section{Faktor Kebijakan Pemerintah}

Pemerintah Kabupaten Karo sendiri telah mengeluarkan kebijakan merelokasi masyarakat di desa-desa yang terdapak erupsi cukup parah, yaitu terdapat 7 desa ( Desa Suka Meriah, Desa Suka Kerah, Desa Semacem, Desa Guru Kinayan, Desa Tepu, Desa Gambir, Desa Huta Tunggal) yang dimana salah satunya itu adalah desa Guru Kinayan. Kebijakan yang di keluarkan pemerintah terbagi menjadi 2 gelombang dan 2 model, untuk gelombang pertama pemerintah merelokasi 3 desa terdampak yaitu Desa Suka Meriah, Desa Suka Kerah, dan Desa Semacem ke daerah relokasi desa siosar dengan di berikan ganti rugi berupa jaminan hidup sebesar Rp.90.000,00 serta tanah seluas 5000 meter beserta rumah untuk setiap keluarga, yang di mana tanah tersebut juga akan di jadikan sebagai ladang.

Tabel 5. Daftar Desa Relokasi Gelombang Pertama

\begin{tabular}{ccc}
\hline No & Nama Desa & Biaya Ganti Rugi \\
\hline 1 & Desa Suka Meria & 5000 meter Tanah dan Rumah \\
2 & Desa Suka Kera & 5000 meter Tanah dan Rumah \\
3 & Desa Semacem & 5000 meter Tanah dan Rumah \\
\hline
\end{tabular}

Sumber: Kepala Desa Rimo Kayu, 2018 
Program relokasi tersebut berjalan dengan baik dan terselenggara dengan sukses sehingga seluruh warga dari 3 desa tersebut sudah di relokasi sepenuhnya ke tempat relokasi desa siosar yang terletak di kecamatan merek, Kabupaten Karo.

Tabel 6. Daftar Desa Program Relokasi Mandiri

\begin{tabular}{cll}
\hline No & Nama Desa & Biaya Ganti Rugi \\
\hline 1 & Desa Guru Kinayan & Rp. 110.000.00 \\
2 & Desa Berastepu & Rp. 110.000.00 \\
3 & Desa Gambir & Rp. 110.000.00 \\
4 & Desa Huta Tunggal & Rp. 110.000.00 \\
\hline \multicolumn{3}{c}{ Sumber: Kepala Desa Rimo Kayu }
\end{tabular}

Sedangkan 4 desa sisanya di lakukan relokasi gelombang kedua dengan model kebijakan yang berbeda, yaitu ke 4 desa ini : Desa Guru Kinayan, Desa Tepu, Desa Gambir dan Desa Huta Tunggal, di berlakukan relokasi mandiri berupa pemberian ganti rugi dari pemerintah sebesar Rp.110.000.000 yang dikelola oleh masyarakat setempat dengan pemilihan Ketua Aron sebagai penanggungjawab beberapa KK namun tetap dalam pengawasan pemerintah.

Berdasarkan hasil wawancara terhadap masyarakat desa Guru Kinayan dan kepala desa Rimo Kayu, dana tersebut ternyata tidak di kelolah secara langsung oleh masyarakat karna dana tersebut di keluarkan pemerintah langsung kepada pihak pengembang atau pihak yang bertugas membangun rumah relokasi untuk warga, ketua Aron yang menjadi pennanggung jawab atas beberapa KK hanya memiliki tanggung jawab untuk menentukan lokasi/tempat pembangunan rumah lalu sisanya baik itu mengenai ukuran rumah, bahan yang di gunakan, model rumah yang akan di bangun menjadi tanggung jawab dan kewenangan dari pihak pengembang dan pemerintah.

Jika di bandingkan antara program relokasi gelombang kedua dengan yang pertama memang terdapat perbedaan yang sangat mencolok, jika di program relokasi gelombang pertama masyarakat hanya tinggal menempati tempat relokasi yang sudah di sediakan namun relokasi gelombang kedua masyarakatlah yang memilih akan di relokasi ke mana dengan dana yang di berikan tersebut, dari segi besaran ganti rugi yang di berikan juga sangat berbeda, sehingga perbedaan tersebut sebetulnya dapat menimbulkan kecemburuan sosial dalam masyarakat, namun hal tersebut barulah sebuah spekulasi dan berdasarkan keterangan yang di berikan masyarakat desa Guru Kinayan, mereka justru lebih menginginkan program relokasi seperti gelombang pertama namun program relokasi mandiri itu sendiri merupakan hasil dari musyawarah antara pemerintah dengan masyarakat.

Kebijakan relokasi yang telah di keluarkan oleh pemerintah baik itu relokasi gelombang pertama ataupun relokasi gelombang kedua memiliki kelebihan dan kelemahan, namun untuk program relokasi mandiri yang di terapkan, pemerintah di nilai kurang serius dalam pengawasan terhadap program tersebut, meski tempat relokasi yang di bangun telah selesai namun masyarakat tidak menempati tempat tersebut, seharusnya pemerintah melakukan pengawasan dan pelarangan untuk tidak menempati zona merah gunung sinabung secara tegas, karna sampai saat penelitian ini di lakukan masyarakat masih tetap tinggal dan beraktivitas seperti biasa di desa tersebut padahal sudah di pasang plakat tanda bahaya dan pemerintah membiarkan hal tersebut, mengingat potensi terjadinya bencana masih sangat besar, walaupun terhitung sejak Maret sampai dengan Desember tidak terjadi erupsi, karna status dari gunung Sinabung sendiri masih berstatus awas ditambah lagi jarak antara desa Guru Kinayan dengan kawah gunung Sinabung hanya berkisar antara $-+3 \mathrm{~km}$.

\section{KESIMPULAN DAN SARAN \\ Kesimpulan}

Desa Guru Kinayan merupakan salah satu di antara tujuh belas desa yang berada dalam radius zona merah gunung Sinabung, desa ini masuk kedalam 7 desa yang mendapatkan bantuan relokasi, 3 desa di relokasi ke desa siosar sedangkan 4 desa lainnya mendapat program relokasi mandiri yaitu berupa pemberian uang ganti rugi senilai Rp. 110.000.000 yang di tujukan untuk membangun rumah kembali. Desa Guru Kinayan termasuk desa yang mendapatkan bantuan relokasi mandiri tersebut, namun walaupun program tersebut sudah di jalankan namun masyarakat di desa Guru 
Kinayan tetap bertempat tinggal di desa tersebut tanpa memikirkan keselamatan mereka sendiri.

Masyarakat di desa Guru Kinayan tetap bertahan di zona merah gunung Sinabung (radius $-+3 \mathrm{~km}$ ) di sebabkan oleh tiga faktor utama, yaitu:

1. Faktor Ekonomi

2. Faktor Pendidikan Anak

3. Faktor Kebijakan Pemerintah

Pemerintah sendiri dinilai kurang tegas dalam pengawasannya, karna membiarkan masyarakat desa Guru Kinayan tetap tinggal dan melakukan aktivitas di desa tersebut walaupun program relokasi telah di lakukan.

\section{Saran}

1. Pemerintah harus segera melakukan peninjauan dan pengawasan yang tegas terhadap masyarakat desa Guru Kinayan yang tetap bertempat tinggal dalam zona merah Gunung Sinabung.

2. Pemerintah harus sesegera mungkin melakukan usaha pemindahan terhadap masyarakat yang tetap tinggal di desa tersebut karna mengingat potensi terjadinya bencana masih cukup besar.

3. Pemerintah di harapkan lebih memperhatikan masyarakat di desa Guru Kinayan, karna pemerintah di nilai hanya melakukan program pemindahan tanpa memastikan program tersebut berjalan secara efektif, karna relokasi bukan hanya memastikan masyarkat tetap memiliki tenpat tinggal tetapi juga harus memastikan keselamatan masyarakat.

\section{DAFTAR PUSTAKA}

BPS Karo. 2017. Kecamatan Payung Dalam Angka. Berastagi : BPSKaro.

Ebo A.G.A. 2010. Gunung Sinabung Meletus. http://www.regional.kompas.com

Fianet. 2014. Sejarah Letusan Gunung Sinabung. Blogspot, Februari 2014 (Online) http://fianetmu.com/2014/02/sejar ah-letusan-gunung-Sinabung-dikabupatenkaro.html) diakses 27 Agustus 2014

Hermon, D. 2009. Dinamika Permukiman dan Arahan Kebijakan Pengembangan Permukiman pada Kawasan Rawan Longsor di Kota Padang Sumatera Barat. Disertasi. PSL. IPB. Bogor.
Hermon, D. 2015. Estimate of Changes in Carbon Stocks on Land Cover Change in the Leuser Ecosystem Area. Forum Geografi. Indonesia Journal of Spatial and Regional Analysis. Vol. 29. Issue 2: 187-196

Hermon, D. 2016.The Strategic Model of Tsunami Based in Coastal Ecotourism Development at Mandeh Regions, West Sumatra, Indonesia. Journal of Environment and Earth Science. Vol. 6. No. 4: 4045

Kantor Kepala Desa Kinayan, 2018. Data Statistik Desa Kinayan.

Oktorie, O. 2018. Model kebijakan responsif pemulihan bencana letusan gunung Sinabung. Jurnal Kapitra Selekta Geografi. Vol. 1. No. 1. 15-20.

Pratomo, I. 2006. Klasifikasi gunung api aktif Indonesia, studi kasus dari beberapa letusan gunung api dalam sejarah. Jurnal Geologi Indonesia. Vol. 1. 209-227.

Supriyono. 2018. Analisis dampak letusan gunung Sinabung kaitannya dengan kondisi sosial ekonomi masyarakat di kabupaten Karo propinsi Sumatera Utara. Jurnal Kapitra Selekta Geografi. Vol. 1. No. 2. 149155.

UPT. Dinas Pendidikan Kecamatan Payung, 2018. Data Kuantitatif Kondisi Pendidikan Kecamatan Payung

UPT. Dinas Pertanian Kecamatan Payung, 2018. Data Kondisi Pertanian Kecamatan Payung. 
available at http://jurnal.unimed.ac.id/2012/index.php/tgeo e-ISSN: 2622-9528 p-ISSN: 2301-606X 